Ann. Biol. anim. Bioch. Biophys., I975, 15 (2), 233-240.

\title{
PROSTAGLANDINS AND SUPEROVULATION IN THE BOVINE
}

\author{
M. PHILliPPO and L. E. A. ROWSON \\ Rowett Research Institute, Bucksburn, Aberdeen, \\ 4. R. C., Unit of Reproductive Physiology, Cambridge, U.K.
}

SUMMARY

Prostaglandin (PG) synchronisation has allowed the use of pregnant mares serum gonadotrophin (PMSG) at different stages of the oestrous cycle. It has been shown that treatment with PMSG after the 8th day of the cycle results in higher mean ovulation rates, a higher number of animals having a large number of fertilised, recoverable eggs compared with treatment given earlier in the cycle. The combination of PMSG treatment with PG synchronisation diminishes the degree of synchrony of ovulation that is obtained with PG treatment alone. Recent work has explored the way in which PG treatment may be used to control the number of ovulations following PMSG treatment on the 15 th day of the cycle. The possible methods of using PMSG and $\mathrm{PG}$ treatments in combination to control superovulation in the cow is discussed.

\section{INTRODUCTION}

Superovulation in the bovine has been induced by the use of pregnant mares serum gonadotrophin (PMSG) given on the $15^{\text {th }}$ or 16 th day of the oestrous cycle (AVERY et al., I962; BROCK and ROWSON, I952 ; GoRdon et al., I962; HAFEZ et al., I963; HAFEZ et al., I965; HAMmoNd and BHATTACHARYA, I944; LAMOND, I97o; LASTER, I973; RowSON, I95I). This technique of superovulation leads a variable number of ovulations and also a variable occurrence of oestrus and of silent oestrus following PMSG treatment (GoRDon et al., I962). The recent use of prostaglandin $P G F_{2 \alpha}$ and its analogues have greatly facilitated the degree to which the oestrous cycle of the cow can be synchronized (TERviT et al., I973; LAURDALE et al., I974; 
Louis et al., I973; LAMOND et al., I973). Preliminary report on the use of PMSG and PG in combination have been reported by 'TERviT et al. (I973) and EILSDEN et al. (I974).

\section{MA'TERIALS AND METHODS}

The experiments were conducted over a period of two years, using two breeds of cattle (Heveford/Friesian and Angus cross heifers). The animals were housed during the duration of the experimental period (usually about one week) whether the experiments were conducted in summer or winter. In summer, the animals grazed at pasture and in winter were fed straw supplemented with a barley concentrated diet. Vasectomized bulls fitted with chin-ball mating harnesses were used to detect oestrus, and the animals were observed at least once a day. The animals were cither mated to entire bulls or artificially inseminated during the oestrus following treatment.

Pregnant mares serum gonadotrophin (Folligon, Intervet Co. Ltd.) was used to induce superovulation; it was made up in sterile diluent at a concentration of 5 oo $\mathrm{IU} / \mathrm{ml}$. Two prostaglandin $F_{2 \alpha}$ analogues were used to synchronize oestrus in the experiments : ICI 79 ,939 was injected intramuscularly at a dose of $800 \mu \mathrm{g}$ and $200 \mu \mathrm{g} 4^{8}$ hours and $7^{2}$ hours after PMSG; ICI 80,996 was injected at a dose of $500 \mu \mathrm{g} 48$ hours after PMSG.

Laparoscopy was performed during oestrus and the subsequent day to determine the number of preovulatory follicles, number of corpora lutea and the occurrence of ovulation. The same technique was also used to determine pregnancy between the 40-7oth days of gestation. Laparoscopy was performed essentially according to the method described by WISHART (I972) except that the animals were only off food and water for a maximum of 8-I 8 hours. A mid-ventral laparotomy was performed under fluothane/oxygen anaesthesia following thiopentone induction 3-4 days after oestrus for egg recovery and the determination of ovarian morphology. The animals were off food and water for only 18 hours prior to anaesthesia.

Samples of blood for hormone analysis were taken from the jugular vein into evacuated tubes containing disodium ethylene diamine tetra-acetate or sodium heparin. They were stored in ice, the plasma separated by centrifugation at $4^{\circ}$ and stored at $-20^{\circ}$ until assayed. Serum luteinizing hormone $\mathrm{LH}$ concentration was assayed against an antiserum raised in rabbits and using NIH bovine-LH as a standard (CHEssworTH and TAIT, I974). The level of sensitivity of the assay for $\mathrm{LH}$ was $0.2 \mathrm{ng} \mathrm{LH} / \mathrm{ml}$ plasma.

\section{RESULTS}

\section{Injection of PMSG and PG during the luteal phase of the cycle}

\section{Ovulatory and oestrous response.}

Thirty-five heifers were injected with I500-2000 IU PMSG at different stages of the oestrous cycle followed by $800 \mu \mathrm{g}$ and $200 \mu \mathrm{g}$ of ICI 79,93948 hours and 72 hours later. Twenty-eight of the animals came into oestrus following this treatment: the number of animals showing oestrus on the $3 \mathrm{rd}, 4^{\text {th }}$ and 5 th days following the initial $\mathrm{PG}$ treatment was $3, \mathrm{I} 8$ and 5 respectively. Twenty-nine animals had ovulated and the details of the response are given in table $\mathrm{r}$.

A similar pattern of ovulatory response was observed from a group of animals treated at Cambridge. The mean ovulatory response for animals treated with lower PMSG between D4-7 was $7.43 \pm \mathrm{I} .4$ (32) compared with $\mathrm{I} 2.3 \pm \mathrm{I} .8(58)$ for those treated between D8-I2 $(\mathrm{P}<0.05)$ : for those treated between Dr3-I6 the mean value was $6.94 \pm 2.7(\mathrm{I} 2)$. 
TABLE I

Effect of day of treatment with PMSG on number of ovulations and of unovulated follicles (> $\mathrm{I} 4 \mathrm{~mm}$ )

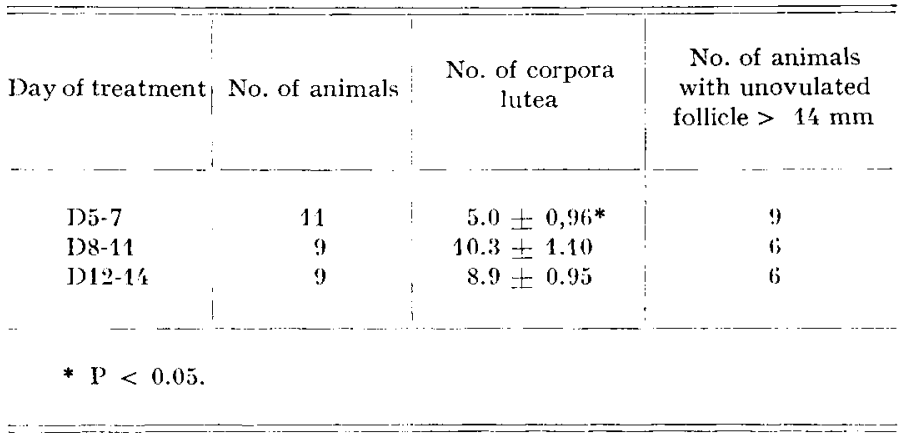

Further analysis of this latter data indicated that a significantly greater nuntber of animals had an ovulation rate of $>8$ or of $>$ Io when they were treated from D8-I2 of the oestrous cycle compared to treatment earlier in the cycle (table 2 ).

TABLE 2

Variation in distribution of ovulations, eggs recovered and fertile eggs recovered with day of treatment with PMSG

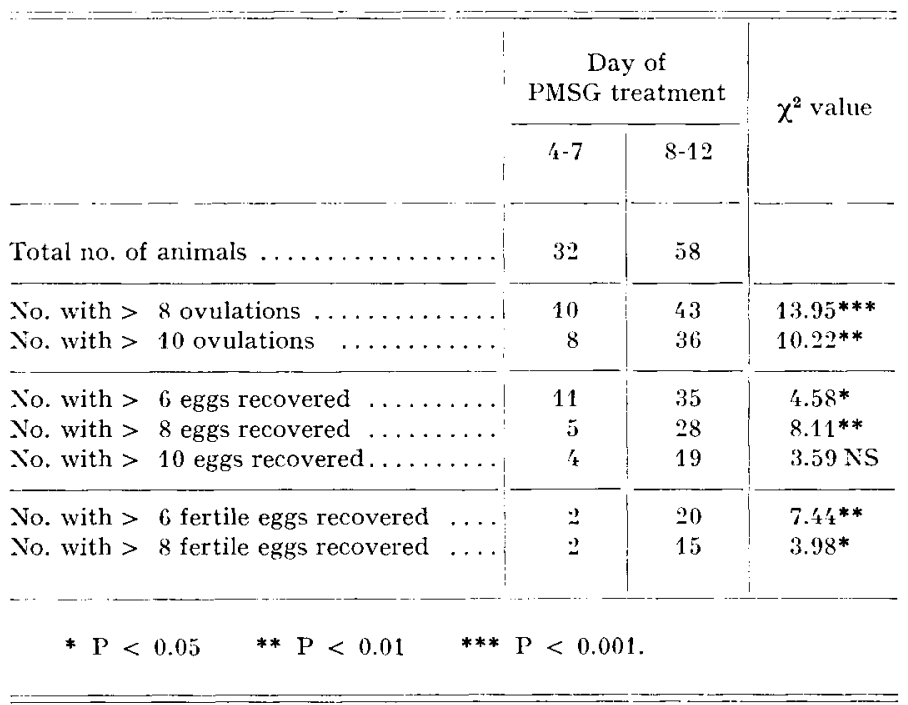

Egg recovery and fertilisation of eggs.

It was found that a higher number of animals treated between the 8-I2th days of the cycle had $>8$ of $>$ Io eggs recovered after operation compared to those 
animals treated earlier (table 2). The number of animals that had more than 6 or more than 8 fertile eggs recovered was also greater in those treated on the 8-I2th days of the oestrous cycle.

\section{Timing of $L H$ release.}

Previous observation indicated that the peak level of luteinizing hormone occurred from $64-72$ hours after injection of the prostaglandin analogue ICI 79,939 the mean value being $68.0 \pm$ I.I (8) hours (unpublished data). The preliminary data available from animals injected with PMSG and PG during the luteal phase of the cycle indicated that the peakof $\mathrm{LH}$ secretion occurs from $4 \mathrm{I}-54$ hours after PG treatment (mean $47.6 \pm 2.0$ hours (5)) : the range of $\mathrm{LH}$ values was from $2.2-49.0 \mathrm{ng} / \mathrm{ml}$. The earlier peak of LH after PMSG treatment is probably indicative of the earlier onset of oestrus that occurs in these animals.

\section{Injection of PMSG during the follicular phase of the oestrous cycle}

Very few animals were treated in the late luteal and in the follicular phase of the oestrous cycle in the previous experiments since the prostaglandin analogue is only effective in synchronizing oestrus when given between the 4 th and the 16 th days of the cycle. There was a suggestion however that the ovulatory response might be slightly lower during the follicular phase of the cycle than that seen on D8-I2 but that the variation might also be greater. An attempt was made to examine whether it would be possible to control ovulation when PMSG was given on DI5 or DI6 of the oestrous cycle.

\section{Ovulatory response.}

A total of $64 \mathrm{HF}$ cows were treated with PMSG on Dr5 or on Di6 of the oestrous cycle, and the number of preovulatory size follicles was determined by laparoscopy during the ensuing oestrus. In addition, 42 of the animals were given $500 \mu \mathrm{g}$ of the prostaglandin analogue ICI 80,99648 hours later. The results of this trial are set out in table 3 . There was no difference between the two treatments in the number

TABLE 3

Effect of different treatments on distribution of follicle numbers

\begin{tabular}{|c|c|c|c|}
\hline$!$ & PIISG & $P M S G+P G$ & $\chi^{2}$ value \\
\hline Total number of animals .... & 22 & 42 & \\
\hline No. with $>2$ follicles $\ldots \ldots$. & 15 & 31 & NS \\
\hline No. with 2 follicles......... & $\underline{2}$ & 16 & $4.48 *$ \\
\hline No. with 2 or 3 follicles ..... & 5 & 21 & $3.39^{*}$ \\
\hline
\end{tabular}


of animals that superovulated. There were however a greater number of animals having only 2 , or 2 or 3 follicles when PMSG and PG treatment was combined indicating that there had been an alteration in the ovarian response.

Oestrous response.

There was a very high incidence of oestrus following PMSG treatment and the pattern of the occurrence of oestrous behaviour is set out in table 4 . It was found that the combination of prostaglandin and PMSG treatment caused a better grouping of the oestrous behaviour : $34 / 42$ animals showed oestrus $4-5$ days after PMSG and $\mathrm{PG}$ treatment compared with $8 / 2 \mathrm{I}$ treated with PMSG alone.

TABLE 4

Effect of treatment on the pattern of oesirous behaviour

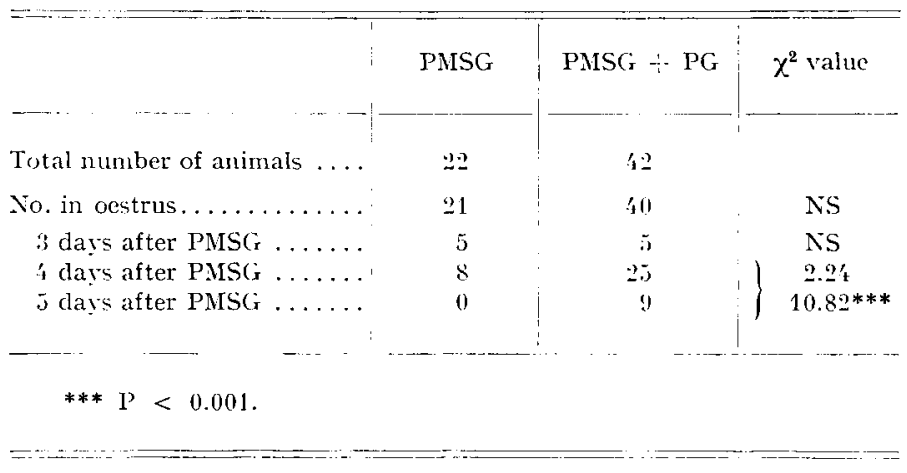

\section{Timing of onulation.}

It had been found that ovulation occurred between 79-9I hours after the injection of ICI 79,939 (unpublished data) and that the analogue 80,996 also caused ovulation at a similar time following treatment. In the present study it was found that the first orulation had occurred in some animals as early as 52 hours after PG (i. e. I02 hours after PMSG) but in others no ovulation had occurred as late as Iro hours after PG (table 5). The two animals in the roo + hour period were possibly

TABLE 5

Incidence of first ovulation after PMSG and PG treatment

Animals with 1 or $>1$ ovulation Animals not ovulating
Hours after $P G$ injection ( $\left.{ }^{1}\right)$

\begin{tabular}{|c|c|c|c|c|c|c}
\multicolumn{8}{c}{ Hours after $P G$ injection (1) } \\
\hline $40+$ & $50+$ & $60+$ & $70+$ & $80+$ & $90+$ & $100+$ \\
\hline & & & & & \\
\hline 0 & 4 & 3 & 4 & 9 & 4 & 1 \\
2 & 6 & 7 & 9 & 2 & & 1 \\
\hline
\end{tabular}

(1) PMSG injected is hours prior to $P G$ injection. 
not typical in that they had a delayed oestrus following PG treatment. Between $5^{\circ-80}$ hours after PG about $50 \mathrm{p}$. Ioo of the animals had one or more ovulation and, although only a few observations were made later than go hours, it would appear that ovulation had started in most animals by that time. It was not possible in this study to say when ovulation had been completed in these animals.

\section{DISCUSSION}

The availability of prostaglandin and of prostaglandin analogues have made it possible to vary experimentally the length of the oestrous cycle of the cow. The use of PMSG and PG in combination during the luteal phase of the oestrous cycle indicate some of the factors responsible for the ovarian response following superovulatory treatment. The main finding from the present study was the differing response of the ovarian follicle population during the different stages of the oestrous cycle. In two separate experiments it was found that the highest ovulatory response was obtained from a greater number of animals during the 8-I2th days of the oestrous cycle. The number of animals with a high number of eggs recovered and of fertile eggs recovered was also significantly greater during this period. EiLSDEx et al. (I974) reported that a combined PMSG and PG used during the mid-luteal phase of the cycle was more effective in terms of oestrous and ovulatory response compared to PMSG given on the 16 th day of the cycle. There are apparently two waves of follicular growth in the cow occurring at the beginning of the oestrous cycle and at the r2-I4th day of the cycle (RAJAKoski, I960; Mariana and Nyugex Hur, I973). The latter authors also demonstrated that PMSG treatment on D6 and on DI6 of the cycle did not alter the proportion of the different types of follicles seen within the ovary (Mariana and NyUGen Huy, I973). Hay and Moor (I973) showed that PMSG injected during the luteal phase of the sheep stimulated the growth and the production of oestrogen from all follicles. The response could be due to the action of PMSG on the medium-sized follicles in the ovary. Other factors may be acting for HENRICKs et al. (I973) found that PMSG had a luteotrophic action on the corpus luteum and that the degree of superovulatory responses is related to the area common to the plasma progesterone/oestrogen curves. This finding would suggest that the elevated progesterone level during the mid-luteal phase and its interaction with the increasing follicular oestrogen production may in part be responsible for the increased ovulation response during the 8-12th days of the cycle.

The combination of PMSG and PG treatment during the follicular phase of the oestrous cycle gave a better synchronization of oestrous than when PMSG is used alone. ELSDEN et al. (I974) found that the number of animals showing oestrus was greater when PMSG and PG was injected during the luteal phase compared to PMSG given alone during the follicular phase of the cycle. Although PG is only effective in causing luteolysis when given between D4 and DI6 (TERVIT et al., I973) its use later in the oestrous cycle will limit the degree of luteotrophic action of PMSG (HeNRICKs et al., I973) and thus lead to a better synchronization of oestrus. The enhanced oestrous response and behaviour may be responsible for the more controlled ovulation rate that was seen in these experiments. 
Most experiments reported to date have used an interval of 2 days between the use of PMSG and PG with the exception of TERviT et al. (I973) who comment that an interval of $I$ or 2 days gave essentially similar superovulatory responses after PMSG treatment. If the superovulatory response does in fact depend upon the interaction of the progesterone/oestrogen balance following treatment then further studies with a variable interval between PMSG and PG would need to be conducted to elucidate this mechanism.

This paper has shown that the combined use of PMSG and PG has greatly enhanced the research into the control of superovulation. The time of the cycle during which their use is most effective in causing superovulation has been demonstrated, and therefore should aid the research on superovulation and synchronisation of the donor animal in studies concerned with egg transfer techniques. The use of PG with PMSG during the follicular phase of the oestrous cycle appears to be a way of controlling multi-ovulation in the cow and thus possibly a step towards controlled multiple pregnancy in the cow.

Colloque : Control of sexual cycles in domestic animals October $27-30,1974$, Nouzilly.

\title{
ACKNOWLEDGEMENTS
}

We are indebted to Imperial Chemical Industries Ltd., for the generous gift of the prostaglandin analogues and to Intervet Co. Ltd., for the generous supply of pregnant mares serum gonadotrophin.

\section{RÉSUMÉ}

\author{
PROSTAGLANDINES ET SUPEROVULATION CHEZ IA VACHE
}

La synchronisation des oestrus avec les prostaglandines a permis l'utilisation de PMSG à différents moments du cycle ostrien chez la Vache. Le traitement avec PMSG après le $8^{\mathbf{e}}$ jour du cycle donne des taux moyens d'ovulation plus élevés qu'avec un traitement donné plus tôt dans le cycle, un nombre plus important d'animaux ayant un grand nombre d'œufs fécondés et récupérés. La combinaison PMSG + PG diminue le degré de synchronisation des ovulations par rapport à celui obtenu avec les prostaglandines seules. Dans un travail récent, il a été étudié la façon avec laquelle le traitement avec prostaglandines doit être utilisé pour contrôler le nombre d'ovulations après traitement PMSG le $I 5$ jour du cycle. Les méthodes possibles d'utilisation des traitements PMSG et prostaglandines ensemble pour contrôler la superovulation chez la Vache sont discutées.

\section{REFERENCES}

Avery T. L., Fahxixg M. L., Graham E.F., I962. Investigations associated with the transplantation of bovine ova. II. Superovulation. J. Reprod. Fert., 3, 21 2-2 I 7.

Brock H., Rowson L. E. A., I952. The production of viable bovine ova. J. Agric. Sci., 42, 479-482. Chesworth J. M., Tait A., I974. A note on the effect of the presence of rams upon the amount of luteinizing hormone in the blood of ewes. Anim. Prod., 19, ro7-r ro. 
Jilsden R. P., Lewis S., Cumming I. A., Lawson R. A. S., r974. Superovulation in the cow following treatment with PMSG and Prostaglandin $\mathrm{F}_{2 \alpha}$. Proc. Aust. soc. Reprod. Biol., abstr. in J. Reprod. Fevt., 36, 455-456.

Gordon I., Williams G., Edwards J., I962. The use of serum gonadotrophin (PMSG) in the induction of twin-pregnancy in the cow. $J$. Agric. Sci., 59, I43-198.

Hafez E.S. E., Jainudeen M. R., Lindsay D. R., I965. Gonadotrophin-induced twinning and related phenomena in beef cattle. Acta Endocrinol., 49, suppl. Io2.

Hafez E.S. E., Sugie T., Gordon I., 1963. Superovulation and related phenomenon in the beef cow. I. Superovulatory responses following PMS and HCG injections. J. Reprod. Fert., 5, 359-379.

Hammond J. (Jr.), Bhattacharya P., 1944. Control of ovulation in the cow. J.agric. Sci, 34, I-I5.

Hay M. F., Moor R. M., I973. The Graafian follicle of the sheep : relationships between gonadotrophins, steroid production, morphology and oocyte maturation. Ann. biol. anim. Biochim. Biophys, 13, No. Hors-Serie, 24I-248.

Henricks D. M., Hill J. R. (Jr), Dickey J. F., Lamond D. R., I973. Plasma hormone levels in beef cows with induced multiple ovulations. J. Reprod. Fert., 35, 225-233.

LAMOND D. R., I970. The effects of pregnant mares serum gonadotrophin (PMSG) on ovarian function of beef heifers as influenced by progestins, plane of nutrition and fasting. A ust. J. agric. Res., 21, I53-159.

Lamond M. R., Tomlinson R. V., Drost M., Henricks D. M., Jochle W., 1973. Studies of prostaglandin $F_{2 \alpha}$ in the cow. Prostaglandins, 4, 269-284.

LASTER D. B., I973. Ovulation, fertility and prenatal mortality in heifers treated with PMSG or porcine FSH. J. Reprod. Fert., 33, 275-282.

Louis T. M., Hafs H. D., Seguin B. E., I973. Progesterone, LH, estrus and ovulation after PGF $2 x$ in heifers. Proc. Soc. exp. biol. Méd., 143, I52-I55.

Mariana J. C., Nyugen Huy N., I973. Folliculogenèse chez la Vache. Ann. Biol. anim. Bioch. Biophys., 13, No. Hors-Série, 2 I I-221.

Rajakoski E., I96o. The ovarian follicular system in sexually mature heifers with special reference to seasonal cyclical and left-right variations. Acta Endocrinol., 34, suppl. 52, I-68.

Rowson L. E. A., I95x. Methods of inducing multiple ovulations in cattle. J. Endocr., 7, 260-270.

Rowson L. E. A., Lawson R. A. S., Moor R. M., I97I. Production of twins in cattle by egg transfer. J. Reprod. Fert., 25, 26I-271.

Tervit H. R., Rowson L. E. A., Brand A., I973. Synchronization of oestrus in cattle using a prostaglandin $\mathrm{F}_{2 \%}$ analogue (ICI 79,939). J. Reprod. Fert., 34, I79-181.

IVIShart 1. F., x 972 . Observations on the oestrous cycle of the Friesian heifer. Vet. Rec., 90, 595-597. 